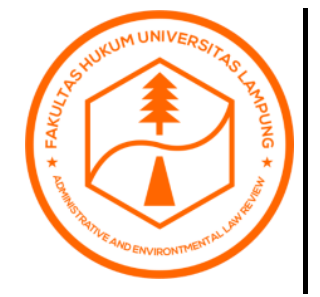

ADMINISTRATIVE AND ENVIRONMENTAL LAW REVIEW

Volume 1 Issue 2, July-December 2020: PP: 83-90

Faculty of Law, Universitas Lampung, Bandar Lampung, Indonesia.

http://jurnal.fh.unila.ac.id/index.php/aelr

P-ISSN: 2723-2484

E-ISSN: $2745-9330$

\title{
Analysis of the Energy and Mineral Source Regulation in the Formulation of Job Creation Law (Omnibus Law)
}

\author{
Indah Dwi Qurbani \\ indah.qurbani80@ub.ac.id \\ Faculty of Law, Universitas Brawijaya Malang \\ Muhammad Rafid Zuhdi \\ rafidzuhdi99@gmail.com \\ Faculty of Law, Universitas Brawijaya Malang
}

Submitted: Sep 10, 2020; Reviewed: Okt 1, 2020; Accepted: Okt 30, 2020

\begin{tabular}{|c|c|}
\hline Article's Information & Abstract \\
\hline $\begin{array}{l}\text { Keywords: Omnibus Law; Energy and } \\
\text { Mineral Resources; Work Creation } \\
\text { Act. } \\
\text { DOI: } \\
\text { https://doi.org/10.25041/aelr.v1i2.2117 }\end{array}$ & $\begin{array}{l}\text { This research is an analysis and evaluation of } \\
\text { the Work Creation Omnibus Law. The } \\
\text { intended Work Creation Act regulates many } \\
\text { sectors, in this study an evaluation and analysis } \\
\text { of the omnibus law in the energy and mineral } \\
\text { resources sector is carried out as regulated and } \\
\text { contained in paragraph five of the Work } \\
\text { Creation Act. This has resulted in pros and } \\
\text { cons and has become an issue of national law. } \\
\text { The omnibus law method is not completely } \\
\text { new to Indonesia. The substance of the } \\
\text { omnibus law has been used in the legislative } \\
\text { process in Indonesia. In terms of the formation } \\
\text { Law Number } 23 \text { of } 2014 \text { concerning Regional } \\
\text { Government, it is a form of omnibus law. The } \\
\text { type of research in this research is normative } \\
\text { legal research, with the nature of prescriptive } \\
\text { and applied research with the aim of evaluating } \\
\text { and analyzing the energy and mineral resources } \\
\text { sector regulations on the formation of the } \\
\text { Work Creation Act. }\end{array}$ \\
\hline
\end{tabular}

Administrative and Environmental Law Review is a journal published by Faculty of Law, Universitas Lampung, under a Creative Commons Attribution-ShareAlike 4.0 International License. 


\section{A. Introduction}

In a situation of uncertainty in society and the issue of a trade war between the United States and China, Indonesia's economic growth will find it difficult to achieve its target. In the first period, there were several aspects that played the main problem, namely the stagnation of the country's economic growth. One of them is the low incoming investment in Indonesia. According to the 2019 Ease of Doing Businesses report, Indonesia's ranking is in 73 (seventy three) out of 160 (one hundred and sixty) countries. Indonesia's ranking is far compared to neighboring Thailand which is at 27 (twenty seven) and Vietnam at 69 (sixty nine).

The next problem is that it takes approximately one month to start and administer a business permit. This can be seen from the aspect of starting a business. Currently, the average permit processing must go through 11 (eleven) procedures, with a time of about 24 (twenty four) days and a cost of 2,780 million rupiah. The new target is that the government will cut procedures down to 9 (nine) procedures, with a length of 9 (nine) days for processing and a cost of 1.58 million rupiah.

The problem in the 2 (two) paragraphs above is one of several reasons submitted by the Government that was used to form the Omnibus Law on the Law on Job Creation (Job Creation Law). What is the Omnibus Law? What is the impact of the Omnibus Law? Whether or not the discourse on the Omnibus Law is applied to the energy and mineral resources sector? Those are some of the questions that have arisen among academics and society in general.

Based on this background, this research analyzes and evaluates the Job Creation Law. The formation of the Job Creation Law, reaps the pros and cons and becomes a national legal issue that will formulate the problem starting from the understanding of the omnibus law, the weaknesses and strengths of the omnibus law, what should be done and the suitability of the substance of the omnibus law with the framework of national legal development, especially in energy and mineral resources sector.

\section{B. Discussion}

\section{Definition ad Concept of Omnibus Law}

In Bryan A. Garner's Black Law Dictionary Ninth Edition, the definition of omnibus is as follows: relating to or dealing with numerous object or item at once; including many things or having various purposes (relating to or dealing with various objects or items at once; including many things or having various purposes. When combined with the word Law, it can be defined as law for all). ${ }^{1}$

The Omnibus Law concept offers solutions to problems caused by too many and overlapping regulation. ${ }^{2}$ There are at least nine other countries that have implemented the Omnibus Law method throughout history. Among others: England, Australia, Germany, Turkey, the Philippines, Cambodia, Vietnam, Malaysia and Singapore.

Law Number 12 of 2011 concerning the Formation of Legislations does not include the concept of the Omnibus Law as one of the principles in the formation of laws. However, the Omnibus Law is not forbidden ${ }^{3}$ The Omnibus Law method is not completely new to Indonesia. Apart from the term, the substance of the Omnibus Law has been used in the legislative process in Indonesia. In terms of the formation and regulation of Law Number 23

\footnotetext{
${ }^{1}$ Agnes Fitryantica, Harmonisasi Peraturan Perundang-Undangan Indonesia melalui Konsep Omnibus Law, Jurnal Gema Keadilan, Volume 6, Edisi III, Oktober - November 2019, pg 302.

${ }^{2}$ Antoni Putra, Penerapan Omnibus Law dalam Upaya Reformulasi Regulasi, Jurnal Legislasi Indonesia, Volume 17 Nomor 1-Maret 2020; pg. 2.

${ }^{3}$ Firman Freaddy Busroh, Konseptualisasi Omnibus Law dalam Menyelesaikan Permasalahan Regulasi Pertanahan, Jurnal Arena Hukum Volume 10, Nomor 2, Agustus 2017, pg 242.
} 
of 2014 concerning Regional Government (UU Pemda) it is a form of the Omnibus Law. Article 409 of the Regional Government Law revokes articles in other laws as well as cancels several laws in their entirety. Law Number 5 of 1962 concerning Regional Companies and Law Number 32 of 2004 concerning Regional Government and its amendments are those that have been completely revoked. Law Number 28 of 2009 concerning Regional Taxes and Regional Levies and Law Number 17 of 2014 concerning the People's Consultative Assembly, the People's Representative Council, the Regional Representative Council, and the Regional People's Representative Council.

\section{Regulations for the Energy and Mineral Resources Sector in the Omnibus Law, Law on Job Creation}

The energy and mineral resources sector is a commodity that controls the lives of many people and has strategic economic potential, is expected to have business sovereignty to be able to develop the capacity of the national economic potential. The concept of democratic macroeconomics in Article 33 of the 1945 Constitution is to realize economic independence based on moral values to place the principle of joint venture based on the principle of kinship in which the components that control the lives of many people are controlled by the state and its management is based on the principles of economic democracy. ${ }^{4}$

On a legal basis, considering the Job Creation Law, it is stated that Article 5 (1), Article 20, Article 27 paragraph (2) and Article 33 of the 1945 Constitution. Discussions on the right to control the state over the surface of the land and the natural contents underneath previously started from a perspective country. This means that initially the state controls everything that is in its sovereign territory and then regulates all the existing potentials and interests through legal mechanisms.

The main principle in Article 33 of the 1945 Constitution is for the maximum welfare of the people in terms of managing its national natural resources. This is important because, through being in the constitution it therefore becomes a responsibility of the state. ${ }^{5}$

Article 38 Paragraph 5 of the Energy and Mineral Resources of the Job Creation Law states that, in order to provide facilities for the community, especially for Business Actors in obtaining Business Licenses from the Energy and Mineral Resources sector, this Law amends, removes, or stipulates several new regulations, which is regulated in: Law Number 4 of 2009 concerning Mineral and Coal Mining as amended by Law Number 3 of 2020 concerning Amendments to Law Number 4 of 2009 concerning Mineral and Coal Mining, Law Number 22 of 2001 concerning Oil and Gas, Law Number 21 of 2014 concerning Geothermal Energy and Law Number 30 of 2009 concerning Electricity.

Based on the phrase to make it easy for the community, especially business actors, in Article 38 of the Job Creation Law above, it show that the purpose of forming the Job Creation Law focuses on business actors. This violates the provisions of the constitution whose emphasis should be on the welfare of the people as mandated by the provisions of Article 33 of the 1945 Constitution. The Job Creation Law does not appear to be oriented towards the concept of a welfare state, which in fact places more importance on business actors in order to increase investment which is certainly a threat to society. Laws and regulations governing mining management are established to ensure that mining activities also strive to achieve community prosperity and welfare.

\footnotetext{
${ }^{4}$ Indah Dwi Qurbani, Urgensi Pembentukan Peraturan Daerah tentang Pertambangan Mineral di Provinsi Jawa Timur, Arena Hukum, Volume 13, Nomor 2, Agustus 2020, pg. 219.

${ }^{5}$ Indah Dwi Qurbani, The Extractive Industries and Society, https://doi.org/10.1016/j.exis.2020.11.017 , pg.6.
} 
So it should be emphasized in the Job Creation Law by using the concept of a welfare state approach, so that the aim of facilitating regulations for the acceleration of the state economy through investment or business in many sectors can still pay attention to the welfare conditions of the community, especially those who live around mining locations.

Article 39 Paragraph 5 Energy and Mineral Resources of the Job Creation Law states that, between Articles 128 and 129 of Law Number 3 of 2020 concerning Amendments to Law Number 4 of 2009 concerning Mineral and Coal Mining 1 (one) article is inserted, namely Article 128A so that it reads as follows: (1) Business actors who increase the added value of coal as referred to in Article 102 paragraph (2) may be given certain treatment of the state revenue obligation as referred to in Article 128. (2) Granting certain treatment (2) the obligation of state revenue as referred to in paragraph (1) for activities to increase the added value of coal may be the imposition of a royalty of $0 \%$ (zero percent). (3) Further provisions regarding certain treatment as referred to in paragraph (1) shall be regulated in a Government Regulation. Phrases can be in the form of imposition of a royalty of $0 \%$ (zero percent) for business actors who increase the added value of coal; this indicates that there is a process of exploitation and "cheap selling" of coal.

This matter can also become a concern related to the State's Right to Control which should be used as much as possible for the prosperity of the people and environmental protection not only for the exploitation of natural resources and business profits. The Job Creation Law was formed with the aim of simplifying existing regulations, but the substance that was designed actually intersects with the principles in the formation of laws and regulations in Law Number 12 of 2011 concerning the Formation of Legislative Regulations. The substance does not show synergy with the Indonesian legal development framework as the main foundation in carrying out the country's constitutional mandate, particularly in the fields of energy and mineral resources.

Regulations related to the formation of statutory regulations as stipulated in Law Number 12 of 2011 concerning the Formation of Laws and Regulations. The Law also has provisions for the evaluation and analysis of relevant laws and regulations in Academic Drafts. This is done to identify and harmonize the complexities of various sectors, laws and regulations that are inconsistent and coherent with the law being drafted. There is a process of synchronization and harmonization of laws and regulations.

This means that even in the current statutory regulation formation mechanism, if the stages in its formation from planning to enactment are implemented and passed properly, it will produce good legislation.

Article 39 Paragraph 5 Energy and Mineral Resources of the Job Creation Law also states that "Anyone who obstructs or interferes with mining business activities from the holder of a Mining Business License, Special Mining Business License, Community Mining Permit or SIPB has met the requirements as referred to in Article 86F letter b and Article 136 paragraph (2) shall be punished with imprisonment of a maximum of 1 (one) year or a maximum fine of Rp. 100,000,000.00 (one hundred million rupiah). " The regulation also shows that conflict resolution between communities around the mine and business actors are rife with criminalization methods where the state should be "present" to resolve the conflict.

Article 40 Paragraph 5 Energy and Mineral Resources of the Job Creation Law also regulate that: several provisions in Law Number 22 Year 2001 concerning Oil and Natural Gas are amended, one of which is the provision of Article 5 in Law Number 22 Year 2001 concerning Oil, Gas, and Earth with the following conditions: Oil and Gas business activities are carried out based on Business Licensing from the Central Government. The provisions of Article 52 of Law Number 22 Year 2001 concerning Oil and Natural Gas are also amended so that it reads as follows: Any person conducting Exploration and / or Exploitation without 
having a Business License or Cooperation Contract shall be sentenced to imprisonment of up to 6 (six) years and a maximum fine of Rp. $60,000,000,000.00$ (sixty billion rupiah).

This regulation also raises questions related to the management of oil and natural gas in the upstream sector whether by means of a cooperation contract or simply with Business Licensing, it also shows the easier management of the upstream sector of natural gas through business licensing and eliminating natural monopoly which should be carried out by the State as mandate of Article 33 of the 1945 Constitution. This also shows that the drafters of the Job Creation Law ignored and did not heed the decisions of the Constitutional Court. There has been a Constitutional Disobedience in this setting.

Article 41 Paragraph 5 of the Energy and Mineral Resources of the Job Creation Law also regulate that: several provisions in Law Number 21 of 2014 concerning Geothermal Energy are amended, among others, mentioning that the Administration of Geothermal Energy by Regional Governments is in accordance with norms, standards, procedures and criteria determined by the Central Government. This indicates the centralization of natural resource management, because this arrangement is also used for all other natural resource management.

Since the formation of the Job Creation Law there have been fundamental changes related to the authority of the Provincial Government and the authority of the Regency / City Government. As part of simplifying regulations related to business licensing in the energy and mineral resources sector, the Job Creation Law reduces the authority of the Provincial Government in granting business permits and the authority to grant business permits to be "centralized" to the Central Government, this is contrary to the provisions in Article 18 paragraph ( 5) The 1945 Constitution.

Law Number 23 of 2014 concerning Regional Government which is a manifestation of the 1945 Constitution related to regional autonomy is also questionable. The regulation on the energy and mineral resources sector that makes doing business easier for business actors in the Job Creation Law removes articles that regulate the authority of the Regional Government with the aim that business actors find it easier to carry out activities in the energy and mineral resource sector.

This violates the principle of decentralization mandated in the provisions of Article 18 of the 1945 Constitution. Local governments are aware of the potential of the region, so that in guidance and supervision, punishment can be carried out better.

Article 42 Paragraph 5 Energy and Mineral Resources of the Job Creation Law also regulates that, several provisions in Law Number 30 of 2009 concerning Electricity are amended as follows: Business Licensing is given to business entities for activities: electricity supply business for public interest provision of electricity for its own interests, and electricity support service businesses, on licensing endeavor to supply electricity for the public interest, including for cross-border power purchase activities. Anyone who operates electricity supply business activities for public interest, electricity supply business for his own interests, and electricity support services business is obliged to fulfill the Business License.

The Job Creation Law changes the provisions of Article 18 of Law Number 30 of 2009 concerning Electricity so that it is regulated as follows: Electricity supply business and electricity support business as referred to in Article 8 are implemented after obtaining Business Licensing. The provisions of Article 19 of Law Number 30 of 2009 concerning Electricity are also amended so that it reads as follows: (1) Business Licenses as referred to in Article 18, are given to business entities for activities: electricity supply business for public interest; electricity supply business for its own interests; and electric power support services businesses. (2) Undertaking Licensing for electricity supply activities for the public interest as referred to in paragraph (1) letter a includes cross-border trading activities. (3) Anyone who 
operates electricity supply business activities for public interest, electricity supply business for his own interests, and electricity support services business must fulfill the Business License as referred to in paragraph (1).

This arrangement shows the liberalization in the electricity sector, which is ideally carried out by the state and used for the prosperity of the people. This also shows that the drafters of the Copyright Act work neglected and ignored the Constitutional Court's decision regarding the Electricity Law.

\section{Information of Nuclear Source}

Article 43 Paragraph 6: Nuclear Source Creation Law also regulates that, in order to provide facilities for the community, especially Business Actors, in obtaining Business Licenses from the Nuclear sector, several provisions in Law Number 10 Year 1997 concerning Nuclear Energy are amended.

Based on the phrase to make it easy for the community, especially business actors, it shows that the objective of the creation of the Job Creation Law focuses on business actors. Whereas for the sake of safety, security, tranquility, health of workers and community members, and protection of the environment, the use of nuclear energy is carried out appropriately and carefully and is aimed at peaceful purposes and the maximum benefit for the welfare and prosperity of the people. This is something that needs to be considered regarding nuclear power.

Furthermore, the Job Creation Law also states that between Article 9 and Article 10 is inserted 1 (one) article, namely Article 9A so that it reads as follows: The Central Government can determine a business entity that carries out mining activities for Nuclear Extraction Materials.

Mining activities can be carried out by state-owned enterprises in collaboration with private-owned companies. Business entities are required to fulfill Business Licensing from the Central Government. Nuclear Mineral Mining includes mining which produces radioactive by-products. Business entities related to mineral and coal mining that produce radioactive byproducts are required to have a Business License from the Central Government.

In the event that an individual or business entity finds radioactive by-products, the perpetrator is obliged to transfer it to the State or state-owned enterprises in accordance with the provisions of laws and regulations. Further provisions regarding mining of Nuclear Minerals and radioactive associated minerals are regulated in a Government Regulation.

This arrangement shows the inconsistency of the government in nuclear regulation. Nuclear power concerns the life and safety of many people; therefore it must be controlled by the state whose use for national development is aimed at realizing a just and prosperous society that is equitable materially and spiritually based on Pancasila and the 1945 Constitution.

\section{Conclusion}

The Omnibus Law is a format for the formation of laws that are comprehensive in nature by helping to regulate the material of other laws which are mutually related to the substance regulated by the amended or formed Law. The formation of 1 (one) Law is carried out by considering all the material provisions which are related directly or indirectly which are regulated in various other Laws simultaneously.

The substance of the articles regulating the energy and mineral resource sector of the Omnibus Law UU Cipta Kerja contradicts the principle of a legal state, namely which is a means of realizing the Welfare Objectives, that law is a means to achieve a common idealized 
goal. The ideals of the law itself, whether institutionalized through the idea of a democratic state or embodied through the idea of a rule of law (nomocracy) are intended to improve the general welfare.

The existence of inconsistencies in the articles regulating the energy and mineral resource sector of the Omnibus LawUU Cipta Kerja with the direction of national law development as Indonesia's national ideals formulated in the Preamble to the 1945 Constitution, the goal of the Indonesian nation as a state is to protect the entire Indonesian nation and all spilled blood Indonesia, promote public welfare, educate the nation's life, and participate in implementing world order based on independence, eternal peace and social justice. The rule of law serves as a means to realize and achieve the four goals of the Indonesian state.

\section{Advice}

1. Natural resources which become national strategic potentials in the social and economic life of the nation and the State must be used for the greatest prosperity of the people, and which belong to the collective people of the people. In the conception put down by the Constitutional Court as an interpretation of Article 33 paragraph (3) of the 1945 Constitution;

2. Rejecting the substantive provisions in the articles that have been analyzed by researchers that regulate the energy and mineral resources sector, the Omnibus Law

3. There are improvements to the process of forming laws which include compliance with the principles of good legislative formation, legal material, legal institutions, law enforcement and legal services as well as public legal awareness.

\section{Bibliography}

A. Books

Abrar Saleng, 2004, Hukum Pertambangan, UII Press, Yogyakarta.

Badan Pembinaan Hukum Nasional, 2018, Analisis dan Evaluasi Hukum Terhadap Ketenagalistrikan, Jakarta: Pusat Analisis dan Pelaporan Hukum Nasional.

Bayu Dwi Anggon dalam Pusat Studi Hukum dan Kebijakan Indonesia, 2019, Kajian Reformasi Regulasi di Indonesia: Pokok Permasalahan dan Strategi Penanganannya, PSHK: Jakarta.

Budiardjo Miriam, Dasar-Dasar Ilmu Politik, (Jakarta :PT. Gramedia Pustaka Utama, edisi revisi kedua, 2008.

Jimly Asshiddiqie, Perihal Undang-Undang di Indonesia, (Jakarta : Sekretariat Jendral Mahkamah Konstitusi Republik Indonesia, 2006).

Moh. Mahfud MD., Politik Hukum di Indonesia, (Jakarta: PT. Pustaka LP3ES Indonesia, 2001).

Muhammad A.S. Hikam, Partisipasi Masyarakat dalam Pembentukan Undang-undang, Bandung, Citra Aditya Bakti, 2005.

Ni Made Ari Yuliartini Griadhi dan Anak Agung Sri Utari, Partisipasi Masyarakat dalam Pembentukan Peraturan Daerah, Jurnal Kertha Patrika Vol. 33 No. 1, Januari 2008.

Peter Mahmud Marzuki, Penelitian Hukum, (Jakarta: Prenada Media, 2005).

Satjipto Rahardjo, Ilmu Hukum, Citra Aditya Bakti: Bandung, 2012.

Sorjono Soekanto, Pengantar Penelitian Hukum (Jakarta: UI-Press, 1986).

B. Journals

Agnes Fitryantica, Harmonisasi Peraturan Perundang-Undangan Indonesia melalui Konsep Omnibus Law, Jurnal Gema Keadilan, Volume 6, Edisi III, Oktober - November 2019.

Antoni Putra, Penerapan Omnibus Law dalam Upaya Reformulasi Regulasi, Jurnal Legislasi Indonesia, Volume 17 Nomor 1-Maret 2020. 
Firman Freaddy Busroh, Konseptualisasi Omnibus Law dalam Menyelesaikan Permasalahan Regulasi Pertanahan, Jurnal Arena Hukum Volume 10, Nomor 2, Agustus 2017.

Indah Dwi Qurbani, Raphael J. Hefron, Arial Thoriq, The Extractive Industries and Society, https://doi.org/10.1016/j.exis.2020.11.017.

Indah Dwi Qurbani, Urgensi Pembentukan Peraturan Daerah tentang Pertambangan Mineral di Provinsi Jawa Timur, Arena Hukum, Volume 13, Nomor 2, Agustus 2020.

C. Regulations

Undang-Undang Dasar Tahun 1945;

Undang-Undang Nomor 11 Tahun 2020 tentang Cipta Kerja;

Undang-Undang Nomor 22 Tahun 2001 tentang Minyak dan Gas Bumi (Lembaran Negara Republik Indonesia Tahun 2001 Nomor 136, Tambahan Lembaran Negara Republik Indonesia Nomor 4152); (Lembaran Negara Republik Indonesia Tahun 2014 Nomor 217, Tambahan Lembaran Negara Republik Indonesia Nomor 5585);

Undang-Undang Nomor 30 Tahun 2009 tentang Ketenagalistrikan (Lembaran Negara Republik Indonesia Tahun 2009 Nomor 133, Tambahan Lembaran Negara Republik Indonesia Nomor 5052).

Undang-Undang Nomor 4 Tahun 2009 tentang isepiPertambangan Mineral dan Batubara (Lembaran Negara Republik Indonesia Tahun 2009 Nomor 4, Tambahan Lembaran Negara Republik Indonesia Nomor 4959) dan Undang-Undang Nomor 3 Tahun 2020; 